UDC 004:[37.016:811.111(045)

\author{
Artur Gudmanian \\ Doctor in Philology, Professor, Vice-Rector for Academic Work \\ National Aviation University, Kyiv, Ukraine \\ ORCID ID 0000-0002-5234-1726 \\ gudman13@i.ua \\ Sergiy Sydorenko \\ $\mathrm{PhD}$ in Philology, Associate Professor, Head of the English Philology and Translation Department \\ National Aviation University, Kyiv, Ukraine \\ ORCID ID 0000-0001-7265-559X \\ svsydorenko@gmail.com
}

\title{
A WEB RESOURCE MAP FOR A UNIVERSITY COURSE IN THE HISTORY OF THE ENGLISH LANGUAGE
}

\begin{abstract}
ICT and the Internet have revolutionized education, in terms of opportunities for distance learning, independent study and resource sharing in particular. However, these new opportunities are not equally utilized across university curricula, with much slower progress in the Humanities than in STEM disciplines. The paper looks at how teaching the History of the English language, a mandatory course for university students majoring in English, can be enhanced through the use of web resources. The use of high quality study resources can help solve a threefold task: shifting the emphasis from the lecturer to the student; raising students' motivation and engagement in the course through independent work and research; and increasing the content quality of the course. The authors developed a map of the Internet resources that can be used in the course in the History of the English language. The map has four segments: digital texts; online dictionaries and translation tools; videos, podcasts, textual materials, databases, timelines, etc.; and online activities. Each of the segments offers a list of the Internet resources which can be recommended for the course. The authors see the major benefits of using these resources in facilitating students' preparation for lectures, practical classes, tests and examinations, changing their overall attitude to the History of English, which is traditionally stigmatized by students as insurmountably hard to master, helping students to see that the course can be engaging and even fun, motivating them to explore the history of the language they study on their own. The critical assessment of the web resources available for the course has revealed that the Internet can offer little for the online activities segment of the developed map, which defines the necessity for academics to invest their effort in developing and sharing exercises, practical assignments, tests and other activities to assist students in mastering the course and provide tools for knowledge assessment.
\end{abstract}

Keywords: Internet-resources; History of the English language; ICT in teaching linguistics; web resource map; digital texts; online historical dictionaries.

\section{INTRODUCTION}

The advent of the Internet has essentially transformed the philosophy of education over the recent decades, delivering earlier unimaginable opportunities and innovative technologies of teaching and learning on the one hand, and posing serious challenges on the other. The very concept of education as a linear process consisting in imparting and receiving knowledge, its transfer from a professor to a student, has been morphing to the idea of a more diverse and complex process of knowledge acquisition and competence formation, where the teacher is no longer an ultimate authority, but rather a guide, advisor and facilitator, and the student's agency is of paramount importance.

"With the advancements of information and communication technology, and the proliferation of technology in education, web-based delivery of education, either called online 
learning or e-learning, has become a focus in education with ever-growing popularity" $[1, \mathrm{p}$. 440]. E-learning in its various forms is democratizing education, making it, alongside its social benefits, accessible virtually to anyone connected to the world web, irrespective of their place of residence, age, gender, financial background, etc. Independent study has received an unprecedented technological impetus, fuelled by the affluence of online resources and cuttingedge educational techniques.

If, at the first stage, the possibilities of incorporating the Internet in education were somewhat limited, especially in developing countries, by insufficient university facilities and poor access to the Internet, at present these are no longer an obstacle - as electronics is getting smaller and more personal, the only thing today's students really need is decent access to the Internet, and that is something every educational institution can take care of. Cloud technologies have contributed to shaping the concept of a virtual learning (or educational) environment - a must-do for any school or college that strives to be competitive.

The problem statement. In Ukraine's context, however, the overall picture is not flawless. The assimilation of the opportunities offered by the Internet and ICT for education appears to be visibly effective mostly in STEM disciplines, whereas the humanities still lag behind. Classical theoretical courses in linguistics and philology, which are the core of the standard curriculum, seem to a large extent to continue existing in the before-Internet age, with the students taking notes of lectures and discussing course material with their professors. Surely, the lectures today are often illustrated by Power Point presentations, students download books from the Internet instead of going to libraries and their knowledge is even accessed via computer tests, so the ICT seems to be here. But in terms of e-teaching and elearning technologies the ice has only started to melt. And the stumbling block is not so much the facilities, as we have already mentioned, but the lack of training and inertia of the teaching staff, who are not adequately motivated to embrace the new technology and methods of teaching. But the truth is, the academics have no choice - university curricula standards in Ukraine have reduced the number of classroom hours and sustain emphasis on students' independent study, which has to be properly organized, resource-supported and monitored. In this situation, there is no alternative for professors of linguistics but to yield their previously formidable position on the podium and begin redeveloping their courses so as to shift the focus to the student, giving them reliable guidance and tools to navigate the course.

From the students' perspective, academics can only remain relevant today if they "go online" - otherwise, in the students' eyes they will inevitably turn into "dinosaurs". This imperative has been convincingly formulated by Neil Selwyn: “... online practices have been part of young people's lives since birth and, much like oxygen, water, or electricity, are assumed to be a basic condition of modern life. ... Thus, in many ways, talking about the Internet and education simply means talking about contemporary education" [2].

Obviously, there is a long way to go with the humanities. Besides overcoming inertia, professors need ICT training and technological assistance in developing their courses. While creating up-to-date e-learning environment, university management will consequently have to give a particular consideration to the humanities segment of the curriculum.

In this paper, we will specifically look at the university course in the History of the English Language, which is mandatory in Bachelor programs in English Philology. This course is fundamental for building the philological and linguistic competence of students majoring in the English language and philology, as it familiarizes them with the evolution of the national literary English language in the context of the history of the English people, providing the students with the understanding of the modern state of the language through the diachronic perspective of how the language was shaping itself [3, p. 5-6].

Across the universities in Ukraine, the course is predominantly taught in traditional way, relying on in-class lectures, textbooks and readers, with elements of ICT introduced in 
the form of Power Point presentations, computer tests and course materials deposited on university web-sites. However, the Internet offers a wealth of resources, particularly texts and dictionaries, which are invaluable for the students of History of English and could make the course much more philological (text-centered), research-oriented, exploratory in nature, and thus more effective and engaging.

Analysis of recent studies and publications. The current approaches to teaching the History of the English Language have been comprehensively presented in several recent publications. In [4] the contributors consider the content of the course, its planning and textbooks. Sample tasks give students opportunity to carry out original research, work with archives and online materials, and study language in their communities. In [5] the authors, who are researchers and teachers working in various fields, among them sociolinguistics, medieval paleography, lexicography, creoles and modern poetry, offer invaluable advice on teaching practice and pedagogy for the course. The major aspects analyzed include the relevance of the course to current university curricula, advice concerning how to handle the broad chronology of the History of English, how to work with oral performances of the earlier forms of English, the relationship of the course to modern multimedia platforms, etc. The latest coursebook on the History of English published in Ukraine in 2016 [3] combines thorough theory with innovative approaches to the course design, making a special emphasis on students' independent work, samples of philological analysis of early English texts, tests for different stages of assessment - students' self-assessment, modular assessment and final assessment tasks.

The use of the Internet resources for educational purposes in general and for teaching specific disciplines has been continuously in the focus of researchers' attention. N. Doğruer, R. Eyyam and I. Meneviş [6] emphasize the vital importance of encouraging students to use the Internet to get information they need in their academic studies. The potential of the Internet to improve the quality of education has been argued by M. Ciglarič and T. Vidmar [7], S. Charp [8], D. Laurillard [9]. The active role of the teacher in organizing, structuring and evaluating the information space has been underlined by M. Nentwich [10]. The idea that the teacher is responsible for guiding their students across the Internet space where many educational materials do not undergo any critical examination or assessment is emphasized in [11].

Selection and use of Internet-based resources and tools in the context of primary school have been the subject of research by W. So et al. [1]. Incorporating Internet resources into classroom practice in English secondary schools has been studied by K. Ruthven, S. Hennessy and R. Deaney [12]. The role of the Internet as an information hub or 'global library' and thus "the most promising medium for deploying educational content" has been accentuated by R.E. Ferdig, P. Mishra, Y. Zhao in [13]. The benefits of the Internet as a gateway to global resources and information sharing have been pointed out by Y. Şahin, S. Balta, T. Ercan [14] and C. Audu [15]. Neil Selwyn in [2] discusses forms of online content sharing that sprung up over the recent decades, among them the Open Education Resource Movement. Edwige Simon argues that "by leveraging the instructional potential of web-based resources, you can increase student engagement, expose them to authentic content, and engage them in collaborative activities that trigger critical thinking and creativity" [16].

Professionally oriented Internet resources and their classification have been the subject of research by Yu. Horun [17], N. Matochkina and A. Kinderknekht [18]. The advantages of using web resources in learning have been discussed by E. Erenchinova and E. Proudchenko [19]. The Russian experience of using Internet resources for educational purposes is presented by Ye. Turutina [20] - the paper offers interesting statistics on the use of the Internet based on social and demographic markers. The place of the Internet in academic research and learning of students in Nigeria was analyzed by O. Apuke and T. Iyendo [21]. The use of the Internet 
resources in teaching specialist disciplines has been researched by O. Alioshyna [22]. The possibilities of educational blogs and webquests in the organization of students' independent work have been studied by L. Darinskaya and G. Molodtsova [23]. The use of electronic resources in resource centers for distance learning was analyzed by O. Konevshchynska [24].

The above-mentioned publications, the list of which can not in the least be considered exhaustive, can serve for professionals teaching specific disciplines in the university curriculum as an encouragement for a deeper and more critical insight into the potential of the Internet resources for enhancing their course delivery and student engagement. The use of the Internet resources in teaching the History of the English Language has not so far been the target of any detailed research, and it is this fact, together with our professional motives arising from the practice of teaching the course, that gave the impetus to this study.

The article's goal is to develop a map of reliable Internet resources that can be used by academics and students in the university course in the History of the English Language, thus advising the both sides of the educational process about the tools that could make the study of this challenging course more source- and research-oriented, more engaging for students who often dread the discipline and, as a result, more amenable for independent study.

\section{RESEARCH METHODS}

The method at the basis of this research relates to the information mapping method used for analysis, organization and presentation of information in various spheres of human activity. The highlight of the mapping method is its ability to produce a graphic representation of information, with visual relationships between its units (elements). In course design, the mapping method has, among other applications, the advantage of raising teachers' and students' awareness of the course structure, interdependence of its constituent parts, their relative value and the educational trajectory to be followed in mastering the course. The mapping method, especially when it comes to mapping resources, is also effective in discovering gaps, or "untrodden lands", thus stimulating work aimed at their coverage.

Auxiliary methods used include categorization of available Internet resources on the History of the English Language, their content analysis and critical assessment in terms of quality, level of difficulty and suitability for the course syllabus.

\section{THE RESULTS AND DISCUSSION}

Besides traditional lectures, three major types of resources are indispensable while developing a university course in History of English, especially for planning practical classes and students' independent work: original texts of the Old English, Middle English and Early Modern English periods, dictionaries and activities for practice (practical assignments), including assessment tools. In the pre-Internet age, professors and students had an access to the texts and dictionaries mostly in the form of readers - selections of fragments from written records representing different periods in the history of the English language and glossaries to them, the editions of complete texts and authoritative etymological dictionaries being confined to a few libraries and thus practically unavailable for general student audience. The arrival of the Internet and massive effort aimed at digitalization of texts and development of educational resources brought about a complete change of the scene. Scholars and students of English have received access to a wealth of textual materials and best dictionaries, which made diachronic studies of the language a home activity. Besides bringing early texts and historical dictionaries to students' PCs, the Internet has considerably expanded the inventory 
of resources which can make both classroom and out-of-class work on the course more engaging.

Thus, when developing our map of web resources for the course in the History of the English Language we supplemented the three mentioned above traditional types of resources with the fourth one, which includes videos, podcasts, and various informative and reference materials, such as readings in the History of English, background historical and linguistic materials, bibliographies, handouts, timelines, detailed chronologies, visual materials, etc.

As a result of our research, we compiled the following map of web resources which can be recommended to the teachers and learners of the History of English:

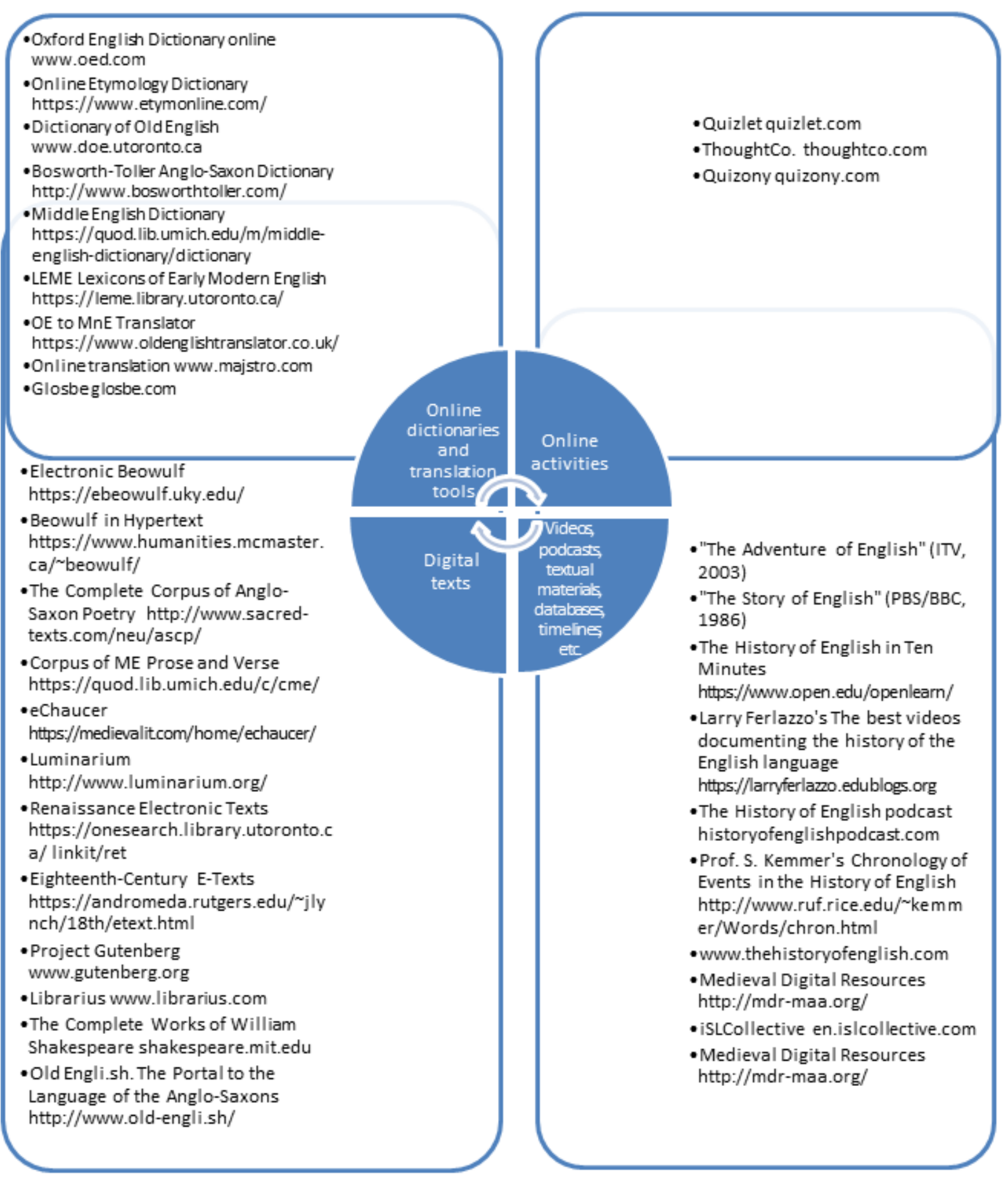




\subsection{Digital texts}

Work with the original texts of the Old English, Middle English and Early Modern English periods is the core of the course in History of English. Reading, translating and analyzing the texts, students get in touch with the real language of various historical periods, through their hands-on experience get aware of the continuity of the language across its history and make insights into the various sociocultural influences that shaped the English nation.

The Complete Corpus of Anglo-Saxon Poetry at http://www.sacred-texts.com/neu/ascp/ is a freely available archive of plain-text electronic editions of Anglo-Saxon poetic works. The Corpus offers only texts, without any commentaries, glossaries or translations.

The text of Beowulf, can be thoroughly studied on Electronic Beowulf 4.1 at https://ebeowulf.uky.edu/. This magnificent online academic resource, edited by Kevin Kiernan and programmed by Ionut Emil Iacob, offers an e-text of the poem, images of the Beowulf manuscript pages, Modern English interlinear translation, comprehensive search facilities, various study and reference tools and a critical apparatus.

Beowulf in Hypertext site (https://www.humanities.mcmaster.ca/ beowulf/) offers a digital text of the poem, its modern translation, description of the characters, information about the original manuscript, its authorship, archeological and cultural background.

Free editions of Anglo-Saxon prose texts can be found on Old Engli.sh. The Portal to the Language of the Anglo-Saxons at www.old-engli.sh. Besides free, downloadable Old English texts, the portal contains study tools, news for linguists dedicated to the study of Anglo-Saxon, useful links and articles.

An extensive searchable collection of Middle English texts can be found in Corpus of Middle English Prose and Verse at https://quod.lib.umich.edu/c/cme/. The Corpus is a part of Middle English Compendium, the other two parts of which are the Middle English Dictionary and a Bibliography of Middle English prose and verse.

Chaucer's texts, which are a mandatory component of the Middle English part of the course in the History of English, can be found on several websites. The complete works of Chaucer and their modern English prose translations are offered by eChaucer at https://medievalit.com/home/echaucer/, created and edited by Prof. Gerard NeCastro. The Canterbury Tales and other Chaucer's works can be found on www.librarius.com. This site contains the original text side by side with the modern English translation and a Middle English glossary. The texts of Chaucer's works can also be found on Project Gutenberg site (www.gutenberg.org.)

The online Anthology of English Literature http://www.luminarium.org/ presents a rich collection of medieval, Renaissance, 17th-century and Restoration literature, accompanied with translations, supplementary study materials, useful bibliographies and links. When studying the Canterbury Tales, students can listen to short recordings of the excerpts from the medieval text.

A series of Early Modern English texts can also be found on Renaissance Electronic Texts at https://onesearch.library.utoronto.ca/linkit/ret. This resource hosts old-spelling, SGML-encoded editions of Shakespeare's Sonnets, Elizabethan Homilies, Robert Cawdrey's A Table Alphabetical of Hard Usual English Words, George Cavendish's The Life and Death of Cardinal Wolsey and Edmund Coote's The English Schoole-Maister.

Shakespeare's works can be accessed online via The Complete Works of William Shakespeare at http://shakespeare.mit.edu/, the first edition of Shakespeare's complete works on the Internet, maintained since 1993.

The online catalogue Eighteenth-Century E-Texts at https://andromeda.rutgers.edu/ jlynch/18th/etext.html gives access to electronic editions of 18th-century works available on the Internet. 


\subsection{Online dictionaries and translation tools}

The Internet not only made copies of the early English texts generally available, but also equipped students of English with the authoritative etymological and historical dictionaries to process these texts. Availability of such comprehensive tools made a difference in terms of developing students' linguistic and philological competence, as they received a unique handson experience in the field of historical lexicography.

The historical and etymological dictionaries available on the Internet are of different types and academic depth, and serve different purposes. If a student needs a quick etymological reference, they can get it in Online Etymology Dictionary at https://www.etymonline.com/. Comprehensive historical information about English words should be sought in Oxford English Dictionary online (www.oed.com), the most respectable English dictionary on historical principles with more than 600,000 words and 3 million quotations. OED requires subscription.

The generally accepted recommendation for in-depth study of the Old English lexicon is the digital version of Bosworth-Toller Anglo-Saxon Dictionary (http://www.bosworthtoller.com/) and Dictionary of Old English (www.doe.utoronto.ca).

Middle English Dictionary (https://quod.lib.umich.edu/m/middle-englishdictionary/dictionary), which is part of the Middle English Compendium created and hosted by the University of Michigan Library, is a digital version of the printed Middle English Dictionary published by the University of Michigan Press in 1952-2001.

For studies in the Early Modern English period, we recommend Lexicons of Early Modern English (LEME) at https://leme.library.utoronto.ca, a database of monolingual, bilingual and multilingual dictionaries, lexical encyclopedias, glossaries of hard words, spelling lists and other works relevant to the lexicon of the period, dating from about 1475 to 1755. This invaluable resource was created by the University of Toronto Library and the University of Toronto Press.

Students of English, who cannot imagine their life today without GoogleTranslate, might be happy to know that Old English vocabulary has been included in some of online translators, among them Old English to Modern English Translator (https://www.oldenglishtranslator.co.uk/) and Online translation (www.majstro.com). The multilingual online dictionary Glosbe (https://glosbe.com/) has both Old English and Middle English options. Naturally, students should be instructed as to the limited scope and specificity of using these three translation resources.

\subsection{Videos, podcasts, textual materials, databases, timelines, etc.}

Among students of linguistics, History of English often has a reputation of a backbreaking, tedious and almost incomprehensible course. However, with a competent professor, once students have embarked on the course, this stereotypical image should gradually dissolve, as they get to see that, though not an easy matter, history of anything, the history of the English language in particular, cannot help being absorbing, eye-opening and even fun. The video, audio, textual and graphic resources available on the Internet today can considerably assist academics in making students more engaged in the course. The advantage of such resources is that they carry the subject of the history of English beyond the classroom, beyond traditional textbooks and dictionaries, making it visual, vibrant with life, speaking in different voices. The students suddenly realize that the discipline they are studying attracts scholars and fans across the globe, they become aware of the immense effort invested by specialists in the field on the international scale. With these resources at hand, the lecturers can finally "sit back" and, instead of trying hard to "force-feed" the information required by 
the syllabus, can let their students read, watch, listen and explore on their own, and experiment with innovative pedagogical strategies, such as flipped classroom, for instance.

Among video resources, two TV series have won universal acclaim, The Story of English (PBS/BBC, 1986) in nine episodes and The Adventure of English (ITV, 2003) in eight episodes. Both of them have been used in university courses in History of English worldwide.

YouTube offers a number of videos on the history of the English language - it is, however, up to the course instructor to assess their quality and suitability. A popular entertaining video gist of the course is The History of English in Ten Minutes consisting of ten one-minute cartoons, which can be found on the Open University website at https://www.open.edu/openlearn/. A list of videos on the history of English is offered by Larry Ferlazzo, an educationalist and author of books on pedagogy from Sacramento, California, in his blog - students can find them by googling Larry Ferlazzo's The best videos documenting the history of the English language.

An impressive audioproject dedicated to the history of the English language is Kevin Stroud's The History of English Podcast (https://historyofenglishpodcast.com/). This spoken history of English, which has been evolving since 2012 and as of July 2019 has 127 episodes, is a result of extensive research and thorough preparation. The author presents the history of English grammar, phonology and vocabulary in the context of the historical events that shaped the English nation. The podcasts combine scholarly standards and captivating narration, incorporating readings from historical English texts.

Textual materials for independent study, as well as other sources and links, can be found at www.thehistoryofenglish.com.

A detailed Chronology of Events in the History of English is offered for public use by Prof. S. Kemmer on his webpage http://www.ruf.rice.edu/ kemmer/Words/chron.html.

A good recommendation for students interested in deeper study of medieval history is Medieval Digital Resources website (http://mdr-maa.org/), developed by the Medieval Academy of America. The project gives access to the resources on the web that contain materials of interest to scholars of the Middle Ages and meet the up-to-date standards of web presentation.

Some free worksheets on various aspects of the history of English can be found at https://en.islcollective.com.

\subsection{Online activities}

Our mapping of the Internet resources for the course in the History of the English Language revealed that this segment remains largely undeveloped, and even if individual enthusiasts create assignments, exercises, tests and other activities for their students, they are not shared on the Internet for public use. In our opinion, there are two major reasons behind this situation - the first is that History of English has not been traditionally regarded as a course which needs any activities besides those related to the routine text analysis, and the second is that, at least in countries like Ukraine, theoretical courses in linguistics have not yet been actively involved in the process of informatization of university education.

Some samples of what can be done in this segment of resources can be seen at https://quizlet.com, https://www.thoughtco.com/ and https://www.quizony.com/ - these sites offer some tests, flashcards and other activities.

\section{CONCLUSIONS AND PROSPECTS FOR FURTHER RESEARCH}

The conducted research is seen as a small step in expanding the educational potential of the History of the English Language, which is a mandatory course in English philology and 
linguistics curricula, increasing its effectiveness and attractiveness for learners via access to web-based resources. The mapping of the Internet resources for the course enabled us to critically assess the quality and suitability of the Internet resources on the history of English for use both in class and in students' independent study and list those of them which in our opinion can be recommended. As a result, we have singled out four types of web resources: digital texts; online dictionaries and translation tools; videos, podcasts, textual materials, databases, timelines, etc.; and online activities. The fourth segment of our map, i.e. online activities, appears to be almost "an untrodden land" and invites academics to invest their effort in developing exercises, practical assignments, tests and other activities to assist students in mastering the course and provide possibilities for knowledge assessment and self-assessment.

The compiled web resource map should be viewed as a proposal to be considered by interested teachers while planning the course and adjusted to their specific academic goals and students' requirements. It is by no means a finished or exhaustive product - it mirrors the ever-changing fabric of the Internet with its constantly developing educational potential.

Prospects for further research logically derive from the need to develop and share online activities and tests for the course in the History of the English Language, the type of resources that is currently very unsatisfactorily represented on the web.

\section{REFERENCES (TRANSLATED AND TRANSLITERATED)}

[1] W.W. M. So, F.N.Y. Ching, S. C. Kong, M.M.H. Cheng, "Teacher's selection and use of Internet-based resources and tools to facilitate learning in primary classrooms" in Education in a technological world: communicating current and emerging research and technological efforts, A. Méndez-Vilas, Ed. Badajos, Spain: Formatex Research Center, 2011, pp. 440-447. (in English)

[2] N. Selwyn, "The Internet and Education” in Ch@nge: 19 Key Essays on How the Internet Is Changing Our Lives. Madrid: BBVA, 2013. [Online]. Available: https://www.bbvaopenmind.com/en/articles/the-internetand-education/. Accessed on: August 15, 2019. (in English)

[3] V. Yevchenko, History of the English Language. Vinnytsya: Nova Knyha, 2016. (in English and Ukrainian)

[4] C. Moore, C.C. Palmer, Ed. Teaching the History of the English Language. Options for Teaching, 2019. (in English)

[5] M. Hayes and A. Burkette, Ed. Approaches to Teaching the History of the English Language. Pedagogy in Practice. Oxford: Oxford University Press, 2017. (in English)

[6] N. Doğruer, R. Eyyam, I. Meneviş, "The use of the Internet for educational purposes", Procedia - Social and Behavioral Sciences, vol. 28, pp. 606-611, 2011. (in English)

[7] M. Ciglarič, T. Vidmar, "Use of Internet Technologies for Teaching Purposes", European Journal of Engineering Education, vol. 23(4), May 2004. [Online] Available: https://www.researchgate.net/publication/2926781_Use_of_Internet_Technologies_for_Teaching_Purposes. Accessed on: August 15, 2019. (in English)

[8] S. Charp, "The millennium classroom”, T.H.E. Journal, vol. 27(10), pp. 10-12, 2000. (in English)

[9] D. Laurillard, "Learning through collaborative computer simulation", British Journal of Educational Technology, vol. 23 (3), pp. 164-171, 1992. (in English)

[10] M. Nentwich, Cyberscience - Research in the age of the Internet. Vienna: Austrian Academy of Science Press, 2003. (in English)

[11] Internet in Education. Support materials for educators. Moscow: UNESCO Institute for Information Technologies in Education, 2003. (in English)

[12] K. Ruthven, S. Hennessy, R. Deaney, "Incorporating Internet resources into classroom practice: pedagogical perspectives and strategies of secondary-school subject teachers", Computers \& Education, vol. 44(1), pp. 1-34, Jan. 2005. (in English)

[13] R.E. Ferdig, P. Mishra, Y. Zhao, "Component architectures and web-based learning environments", Journal of Interactive Learning Research, vol. 15, pp. 75-90, 2004. (in English)

[14] Y.G. Şahin, S. Balta, T. Ercan, "The use of Internet resources by university students during their course projects elicitation: a case study", Turkish Online Journal of Educational Technology, vol. 9 (2), pp. 234244, 2010. (in English)

[15] C. Audu, "Internet availability and use by postgraduate students of University of Nigeria, Nsukka", Global Review of Library \& Information Science, vol. 2, pp. 34-43, 2006. (in English) 
[16] E. Simon, "Teaching With Web-Based Resources". [Online] Available: https://www.edutopia.org/ blog/teaching-with-web-based-resources-edwige-simon. Accessed on: August 15, 2019. (in English)

[17] Yu. Horun, "Professionally oriented Internet-resources and their classification", Young Scientist, vol. 3 (43), pp. 366-371, March 2017. (in Ukrainian)

[18] N. Matochkina, A. Kinderknekht, "Internet-resources in foreign language study", Philological Sciences. Issues of Theory and Practice, Tambov: Gramota, vol. 11(41), part 1, pp.139-141, 2014. (in Russian)

[19] E. Erenchinova, E. Proudchenko, "Advantages of WEB resources use in learning process", Advances in Social Science, Education and Humanities Research (ASSEHR), vol. 97, pp. 103-108, 2017. (in English)

[20] Ye. Turutina, "The use of Internet resources for educational purposes: Russian experience", Uchenyie Zapiski Kazanskogo Yuridicheskogo Instituta MVD Rossii, vol. 1, pp. 17-21, 2016. (in Russian)

[21] O. Apuke, T. Iyendo, "University students' usage of the internet resources for research and learning: forms of access and perceptions of utility", Heliyon, vol. 4, issue 12, 17 December 2018. [Online]. Available: https://www.heliyon.com/article/e01052. Accessed on: August 16, 2019. (in English)

[22] O. Alioshyna, "The use of Internet-resources in teaching specialist disciplines", Young Scientist, vol. 23 (127), pp. 449-451, Nov. 2016. (in Russian)

[23] L. Darinskaya, G. Molodtsova, "The Opportunities of Educational Internet Resources in the Development of Students' Research Skills (on the Example of Webquest and Educational Blog)" in E-Learning as a SocioCultural System: A Multidimensional Analysis. IGI Global, 2014, pp. 43-62. (in English)

[24] O. Konevshchynska, "Electronic educational resources within information support of distance education resource center", Information Technologies and Learning Tools, vol. 43, issue 5, pp. 164-173, 2014. (in Ukrainian).

Text of the article was accepted by Editorial Team 08.01.2020

\title{
КАРТА ІНТЕРНЕТ-РЕСУРСІВ ДЛЯ УНІВЕРСИТЕТСЬКОГО КУРСУ 3 ІСТОРІї АНГЛІЙСЬКОЇ МОВИ
}

\section{Гудманян Артур Грантович}

доктор філологічних наук, професор, проректор з навчальної роботи

Національний авіаційний університет, м. Київ, Україна

ORCID ID 0000-0002-5234-1726

gudman13@i.ua

\section{Сидоренко Сергій Іванович}

кандидат філологічних наук, доцент, завідувач кафедри англійської філології і перекладу

Національний авіаційний університет, м. Київ, Україна

ORCID ID 0000-0001-7265-559X

svsydorenko@gmail.com

\begin{abstract}
Анотація. ІКТ та глобальна мережа Інтернет докорінно змінили освіту, зокрема відкривши нові можливості для дистанційної освіти, організації самостійної роботи студентів та обміну навчальними ресурсами. Проте цей інноваційний потенціал набагато повільніше реалізується в галузі гуманітарних дисциплін порівняно зі STEM-дисциплінами. Автори статті розглядають можливості підвищення якості викладання університетського курсу 3 історії англійської мови, який є обов'язковим компонентом ОПП для студентів, що вивчають англійську мову та філологію, шляхом залучення навчальних Інтернет-ресурсів. Використання вебресурсів високої якості дозволяє вирішити три головні завдання: змістити акцент з викладача на студента; підвищити мотивацію студентів, їхню зацікавленість дисципліною через активізацію дослідницького компонента навчання; та підсилити змістовну якість курсу. Авторами розроблена карта Інтернет-ресурсів, що можуть бути використані викладачами та студентами в курсі з історії англійської мови. Запропонована карта має чотири сегменти: електронні тексти; онлайн словники та перекладачі; відео, подкасти, текстові навчальні матеріали, бази даних, хронології тощо; онлайн завдання, вправи і тести. Кожен із сегментів карти містить список перевірених Інтернет-ресурсів, що рекомендовані викладачам як можливі для використання в процесі викладання дисципліни та організації самостійної роботи студентів. На думку авторів, основні переваги використання запропонованих ресурсів полягають у підвищенні якості підготовки студентів до лекційних та практичних занять, тестів та екзаменів, а також у зміні їхнього ставлення до дисципліни, яка традиційно має репутацію «непосильної» для опанування, демонстрації
\end{abstract}


того, що історія взагалі, а надто історія мови, яку студенти вивчають, не може бути нецікавою. Критична оцінка наявних Інтернет-ресурсів показала, що сегмент «онлайн завдання, вправи і тести»є значно недозабезпеченим, що визначає перспективу подальшої начально-методичної роботи фахівців, яка повинна бути спрямована на розробку та онлайн поширення якісних практичних завдань, вправ та тестів 3 дисципліни.

Ключові слова: Інтернет-ресурси; історія англійської мови; IКТ у викладанні лінгвістичних дисциплін; карта вебресурсів; електронні тексти; онлайн словники на історичних принципах.

\title{
КАРТА ИНТЕРНЕТ-РЕСУРСОВ ДЛЯ УНИВЕРСИТЕТСКОГО КУРСА «ИСТОРИЯ АНГЛИЙСКОГО ЯЗЫКА»
}

\author{
Гудманян Артур Грантович \\ доктор филологических наук, профессор, проректор по учебной работе \\ Национальный авиационный университет, г. Киев, Украина \\ ORCID ID 0000-0002-5234-1726 \\ gudman13@i.ua
}

\section{Сидоренко Сергей Иванович}

кандидат филологических наук, доцент, заведующий кафедрой английской филологии и перевода Национальный авиационный университет, г. Киев, Украина

ORCID ID 0000-0001-7265-559X

svsydorenko@gmail.com

\begin{abstract}
Аннотация. ИКТ и глобальная сеть Интернет коренным образом изменили образование, в частности открыв ранее невиданные возможности для дистанционного образования, организации самостоятельной работы студентов и обмена учебными ресурсами. Однако данный инновационный потенциал не так быстро реализуется в области гуманитарных дисциплин по сравнению со STЕМ-дисциплинами. Авторы статьи рассматривают возможности повышения качества преподавания университетского курса по истории английского языка, который является обязательным компонентом подготовки специалиста в области английской филологии, путем инкорпорирования в него учебных Интернетресурсов. Использование качественных веб-ресурсов позволяет решить три задачи: сместить акцент с преподавателя на студента; повысить мотивацию студентов, их заинтересованность в изучении дисциплины путем активизации исследовательского компонента обучения; повысить содержательное качество курса. Авторами разработана карта Интернет-ресурсов, которые могут быть использованы преподавателями и студентами в курсе по истории английского языка. Предлагаемая карта имеет четыре сегмента: электронные тексты; онлайн-словари и переводчики; видео, подкасты, тестовые учебные материалы, базы данных, хронологии и т.п.; онлайн-упражнения, задания и тесты. Каждый сегмент карты содержит список проверенных Интернет-ресурсов, рекомендуемых преподавателям для рассмотрения при планировании учебного процесса. По мнению авторов, основные преимущества использования предлагаемых ресурсов состоят в повышении качества подготовки студентов к лекционным, практическим занятиям, тестам и экзаменам, а также в изменении их отношения к данной дисциплине, которая традиционно имеет у студентов репутацию «неподъемной». Привлечение Интернетресурсов поможет продемонстрировать, что изучение истории английского языка, как и истории вообще, может быть увлекательным занятием. Критическая оценка доступных Интернет-ресурсов показала, что сегмент «онлайн-упражнения, задания и тесты» является малообеспеченным ресурсами, что определяет необходимость в разработке и публикации онлайн качественных упражнений, практических заданий и тестов по данной дисциплине.
\end{abstract}

Ключевые слова: Интернет-ресурсы; история английского языка; ИКТ в преподавании лингвистических дисциплин; карта веб-ресурсов; электронные тексты; онлайн-словари на исторических принципах.

\section{(cc) BY-NC-SA}

This work is licensed under Creative Commons Attribution-NonCommercial-ShareAlike 4.0 International License. 